\title{
Experimental Study on Effect of Varying L/D Ratios of Steel Slag Columns on Bearing Capacity of Soft Clay
}

\author{
K. Vaitheswari ${ }^{1}$ and S. Sathyapriya ${ }^{2}$ \\ ${ }^{1}$ PG Student, ${ }^{2}$ Assistant Professor \\ Department of Civil Engineering, Government College of Technology, Coimbatore, Tamil Nadu, India \\ E-Mail:vaithekeshore@gmail.com, sathyapriya@gct.ac.in
}

\begin{abstract}
Rapid urbanisation and growth of infrastructure in the present days resulted in dramatic increase in demand for land space. Presence of soft clay deposits in construction sites poses major problems to the structure resting on it during or after construction. A different approach for stabilization has been obtained by incorporation of steel slag columns, which is a by-product of steel manufacturing industry. Straight shafted granulated steel slag column group was adopted for which the ultimate load carrying capacity was derived from the lateral resistance offered by the surrounding soil. Floating type steel slag columns resting on soft clay layer was arranged in equilateral triangular pattern. This pattern of arrangement was preferred as it was known to provide a more uniform consolidation between columns as per IS 15284 (part 1).Well graded granulated steel slag of size range $2 \mathrm{~mm}-10 \mathrm{~mm}$ with specific gravity 3.57 and moisture content $2.76 \%$ was used. It also had an abrasion value, impact value and crushing strength of $5.47 \%, 27.75 \%$ and $39.38 \%$ respectively. A comparison was made between unreinforced and reinforced soil and variations in bearing capacity and settlement was determined for different $L / D$ ratios. $L / D$ ratios of $3,5,6,8,10$ for steel slag columns has been adopted .Settlement reduction factors for reinforced clay bed was found to be $1.75,1.85,2.53,4.1,6.1$ times of unreinforced clay soil for the $L / D$ ratios of 3, 5, 6, 8, 10 respectively. The bearing capacity factor Nc was obtained as $5.51,9.09,12.670,15.71,20.26,24.83$ for different $L / D$ ratios of $3,5,6,8,10$.
\end{abstract}

Keywords: Stone columns, Granulated steel slag, Triangular pattern, Settlement reduction factor

\section{INDRODUCTION}

Nowadays the development of infrastructures and rapid urbanisation has increased demand for land space. The structures constructed on soft clays experience several problems like excessive settlement, large lateral flow of soft clay beneath the structures and loss of local stability. Several remedial measures are available to overcome the problems among which stone column technique proves to be more effective in terms of load carrying capacity and settlement reduction. The stone column technique was adopted in 1960s [10] in European countries and now it has been successfully implemented. The stone column technique has been widely used as a method of reinforcement for soft soil in highway facilities, embankments, storage tanks and foundation construction. The stone columns are nothing but vertical column elements formed below the ground level with compacted and uncemented stone fragments or gravel or sand. The presence of columns creates a composite material which is stiffer and stronger than the original [10]. The granular column derives their load - bearing capacity by mobilizing the passive earth pressure from the surrounding soft against bulging [7]. The main purpose of stone column is to accelerate the primary consolidation of foundation soil by means of the following two mechanisms. First, the column permeability causes radial drainage which results in faster dissipation of excess pore water pressure and second, the column stiffness reduces the vertical stress on soil body.

A different approach for the solution has been obtained by incorporation of steel slag columns. Steel slag is a byproduct of steel manufacturing industry. Black cotton soil makes construction difficult because of its high compressibility characteristics. Introduction of steel slag column can overcome this difficulty and helps in reducing the compressibility. Steel slag column consists of straight shafted column filled with granulated steel slag. The ultimate load carrying capacity of the steel slag column is derived from the lateral resistance offered by the surrounding soil. The steel slag columns are arranged in equilateral triangular pattern [4]. This pattern of arrangement is preferred since it gives the densest packing and this pattern provides a more uniform consolidation between the columns as per IS 15284 (PART 1).

In floating type steel slag columns, the steel slag columns are rested on a soft clay layer. However in general, the steel slag columns are carried to a rigid stratum passing the overlying soft clay layers. The size of the granulated steel slag lies in the range of $2 \mathrm{~mm}-10 \mathrm{~mm}$. The moisture content of which was found to be $2.76 \%$ and specific gravity was 3.57. Sieve analysis was carried out for particle size gradation of the granulated steel slag which concluded the sample to be well graded. The sample owns an abrasive value, impact value and crushing strength of 5.47\%, 27.75\% and $39.38 \%$ respectively.

\section{A. Objectives}

The main objectives of this work are to study the load settlement behaviour of soil when reinforced with steel slag columns and to study the effect of length to diameter ratio of steel slag columns.To analyze steel slag columns by varying $\mathrm{L} / \mathrm{D}$ ratios and check the modifications in bearing 
capacity and settlement. Finally unreinforced and reinforced soil responses to the applied loads were compared.

\section{MATERIAL PROPERTIES}

\section{A. Materials}

For the present study clay and electric arc furnace slag where used. Clay was collected from GCT Coimbatore at a depth of $1.5 \mathrm{~m}$ from the surface. Electric arc furnace slag was collected from Kiscol TMT, Coimbatore. It was crushed into required size between $2 \mathrm{~mm}$ to $10 \mathrm{~mm}$ for the present study. Properties of each material are listed in table 1 and 2 given below.

TABLE I PROPERTIES OF CLAY

\begin{tabular}{|l|c|}
\hline \multicolumn{1}{|c|}{ Properties } & Values \\
\hline Specific gravity & 2.74 \\
\hline Initial moisture content & $13.39 \%$ \\
\hline Liquid limit($\left(\mathrm{W}_{\mathrm{L}}\right)$ & $60 \%$ \\
\hline Plastic limit($\left(\mathrm{W}_{\mathrm{P}}\right)$ & $29.87 \%$ \\
\hline Shrinkage limit($\left(\mathrm{W}_{\mathrm{S}}\right)$ & $47.5 \%$ \\
\hline Plasticity index($\left(\mathrm{I}_{\mathrm{P}}\right)$ & $30.13 \%$ \\
\hline Differential free swell index & $60 \%$ \\
\hline Optimum moisture content & $18 \%$ \\
\hline Maximum dry density & $1.76 \mathrm{~g} / \mathrm{cc}^{2}$ \\
\hline $\begin{array}{l}\text { Unconfined compressive } \\
\text { strength at OMC }\end{array}$ & $240.8 \mathrm{kN} / \mathrm{m}^{2}$ \\
\hline Cohesion( $\left.\mathrm{C}_{\mathrm{u}}\right)$ & $120.4 \mathrm{kN} / \mathrm{m}^{2}$ \\
\hline
\end{tabular}

TABLE II ELECTRIC ARC FURNACE SLAG

\begin{tabular}{|l|c|}
\hline \multicolumn{1}{|c|}{ Properties } & \multicolumn{1}{c|}{ Values } \\
\hline Size range & $2 \mathrm{~mm}-10 \mathrm{~mm}$ \\
\hline Impact value & $27.75 \%$ \\
\hline Water absorption & $2.76 \%$ \\
\hline Specific gravity & 3.57 \\
\hline Maximum dry density & $16.82 \mathrm{kN} / \mathrm{m}^{3}$ \\
\hline Crushing value & $39.38 \%$ \\
\hline Sieve analysis & $\begin{array}{c}\mathrm{C}_{\mathrm{u}}=11.01 \\
\mathrm{C}_{\mathrm{c}}=1.47\end{array}$ \\
\hline
\end{tabular}

\section{B. Preparation of soft clay bed and installation of columns}

The representative clay sample was collected at a depth of $1.5 \mathrm{~m}$ from the ground surface at Government College of Technology, Coimbatore. Proper care was taken to avoid loss of moisture before testing. A relationship between water content and undrained shear strength of clay was obtained by conducting series of unconfined compressive strength test. Up to an area replacement ratio of $10 \%$ there occurs no bulging, [4 ] therefore in this study area replacement ratio of $9.6 \%$ is provided. The water content needed to prepare soft clay bed of undrained shear strength of $41 \mathrm{kPa}$ was found to be $34 \%$, which has a liquidity index of 1.04.The air-dried and pulverized clay sample of required quantity passing through $4.75 \mathrm{~mm}$ IS Sieve was taken and water content is chosen based on unconfined compressive strength test values and is mixed with the clay sample. The mixture is filled in three layers providing uniform compaction for each layer with hammer. The soil is filled in tank and compaction has been done. Care is taken to ensure the final thickness of each layer is $10 \mathrm{~cm}$ with uniform density of $15.72 \mathrm{kN} / \mathrm{m}^{3}$. The procedure is continued till the final thickness of the soil bed is reached. After the preparation of clay bed, it was completely covered with wet gunny bags to avoid loss of moisture by evaporation and the soil was subjected to seating pressure of $5 \mathrm{kPa}$ to regain part of its strength. A curing period of 24 hours has been allowed to ensure equal spreading of water in the sample.

Steel slag column groups were left floating in the clay. The columns were placed in a triangular pattern. As per IS 15284 the tank is first filled with clay up to a height of $15 \mathrm{~cm}$ [4] from the bottom after which open ended pvc pipe casing of diameter $2.5 \mathrm{~cm}$ were placed as shown in Fig 1 and it is filled around with clay sample. Crushed steel slag is filled in the hole in layers, casing pipe is gradually lifted and the steel slag is compacted with a tamping rod of 10 $\mathrm{mm}$ diameter and $1 \mathrm{~m}$ long with 25 numbers of blows falling freely from a height of $250 \mathrm{~mm}$. This method of compaction gave a dry density of $16.82 \mathrm{kN} / \mathrm{m}^{3}$. The procedure is continued till the entire length of the steel slag column is formed as shown in Fig 2.

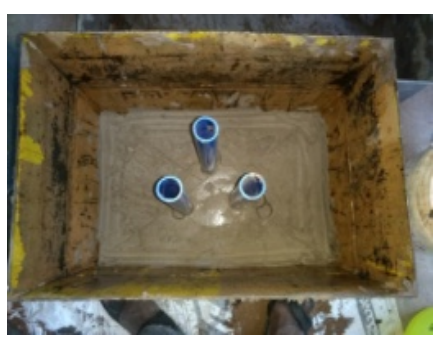

Fig. 1 Preparation of Clay Bed

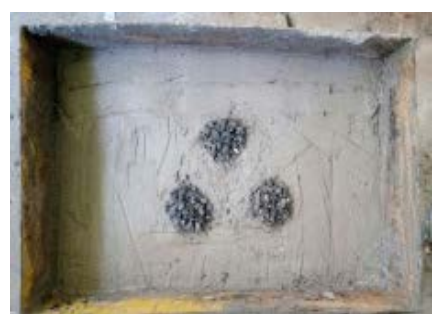

Fig. 2 Steel Slag Column Group on Clay Bed

\section{Load Test}

The model tank containing the clay bed is reinforced with 
steel slag column and is placed in the loading frame. Loading plate of diameter $14 \mathrm{~cm}$ is placed over the steel slag column group, such that its center coincides with the center of the loading plate. Proving ring of capacity $50 \mathrm{kN}$ is used to measure the load and two LVDT's were fixed for measuring the settlement. The loading frame setup is shown in Fig 3. The load is then applied slowly at a strain rate of $2.5 \mathrm{~mm} / \mathrm{min}$ and corresponding settlement for each load increments are noted. The procedure is continued until the failure load is attained and the results are plotted. For different $\mathrm{L} / \mathrm{D}$ ratios of steel slag column group the same procedure is repeated.

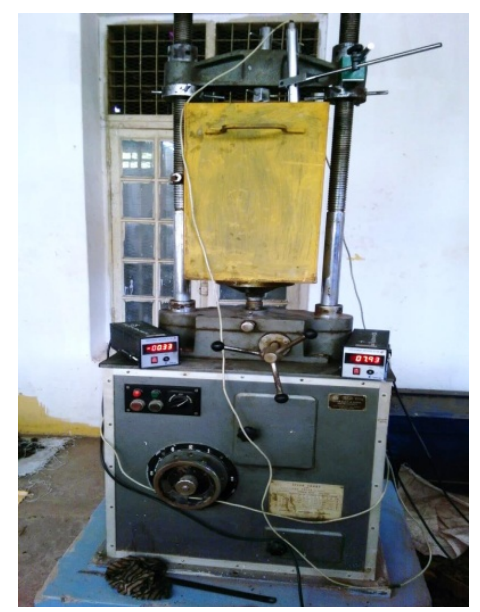

Fig 3 Application of Load

\section{RESULTS AND DISCUSSION}

The following are the results obtained by performing the lab test in the clay bed at different conditions.

\section{A.Load settlement response of plain clay bed}

Fig. 4 shows the load settlement curve obtained from load test on plain clay bed. The failure load carrying capacity of the clay bed is $1.74 \mathrm{kN}$. The settlement at the failure load is

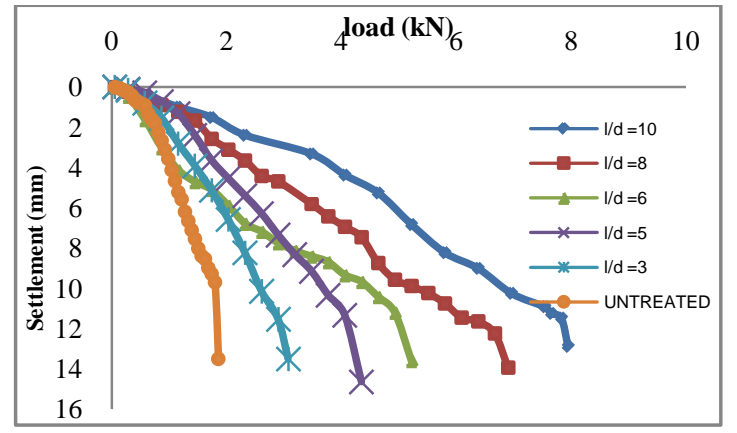

Fig.4 Load versus Settlement Curve

As per IS 2911:1979 safe load on column is given as the least of the following two conditions

1. When $2 / 3$ of load is applied on the column, the settlement of the column is $12 \mathrm{~mm}$
2. When $1 / 2$ of the load is applied on the column, the settlement of the column is $10 \%$ of the column diameter.

The curves indicate almost linear behaviour in the beginning followed by non-linear behaviour leading to continuous deformation as the load increases. The failure load of each case is listed in Table III.

\section{TABLE III FAILURE LOAD VALUES}

\begin{tabular}{|l|c|}
\hline \multicolumn{1}{|c|}{ Soil Column System } & Failure load, $\mathbf{Q}_{\mathbf{f}} \mathbf{( k N )}$ \\
\hline Untreated clay bed & 1.74 \\
\hline Steel slag column of $\mathrm{L} / \mathrm{D}=3$ & 2.87 \\
\hline Steel slag column of $\mathrm{L} / \mathrm{D}=5$ & 4 \\
\hline Steel slag column of $\mathrm{L} / \mathrm{D}=6$ & 4.96 \\
\hline Steel slag column of $\mathrm{L} / \mathrm{D}=8$ & 6.43 \\
\hline Steel slag column of $\mathrm{L} / \mathrm{D}=10$ & 7.84 \\
\hline
\end{tabular}

\section{B.Bearing Capacity Improvement Factor}

The improvement in the failure pressure intensity of a reinforced soil system can be expressed by bearing capacity improvement factor $\left(\mathrm{F}_{\mathrm{b}}\right)$, which is, $F_{b}=\left(Q_{f}\right)_{\mathrm{r}} /\left(Q_{f}\right)_{\mathrm{u}}$ where $\left(Q_{\mathrm{f}}\right)_{\mathrm{r}}$ is failure load of reinforced clay bed and $\left(\mathrm{Q}_{\mathrm{f}}\right)_{\mathrm{u}}$ is failure load of unreinforced clay bed [11].

The value of $F_{b}$ for reinforced clay bed and unreinforced clay bed are $1.7,2.3,2.85,3.7,4.5$ times the $\mathrm{L} / \mathrm{D}$ ratios of $3,5,6,8,10$ respectively.

The reason for increase in bearing capacity is due to increasing adhesion between the soil particles and steel slag and this reduces the deformation due to distortion or compressibility of the soil mass [3]. Thus stone column provides a lateral confinement which leads to increase in the bearing capacity. The bearing capacity factors $\mathrm{N}_{\mathrm{C}}$ are obtained as 5.51, 9.09, 12.670, 15.71, 20.26, 24.83 with different $\mathrm{L} / \mathrm{D}$ ratios of 3, 5, 6, 8, 10 respectively.

\section{Settlement Reduction Factor}

The settlement reduction factor is used as a measure for the improvement of ground and it is defined as the ratio of settlement of unreinforced ground to the settlement of reinforced soil $\left(\mathbf{F}_{\mathbf{s}}=\mathbf{S}_{\mathbf{u}} / \mathbf{S}_{\mathbf{r}}\right)$. The settlement values of reinforced soil, corresponding to failure load of unreinforced soil are $6.58 \mathrm{~mm}, 5.89 \mathrm{~mm}, 4.54 \mathrm{~mm}, 3.1 \mathrm{~mm}$ and $2.39 \mathrm{~mm}$ with different $\mathrm{L} / \mathrm{D}$ ratios of 3,5,6, 8 and 10 respectively.

\section{CONCLUSIONS}

Following conclusion can be drawn from the study.

1. Load carrying capacity of clay is improved by providing steel slag column group effectively in triangular pattern.

2. The load carrying capacity of reinforced clay bed increases by $39.37 \%$, 56.5\%, 64.9\%, 72.93\%, 77.8\% 
with $\mathrm{L} / \mathrm{D}$ ratios of $3,5,6,8,10$ respectively when compared with unreinforced clay bed.

3. The bearing capacity factors increases with increase in $\mathrm{L} / \mathrm{D}$ ratios.

4. The settlement reduction factor of reinforced clay bed is $1.75,1.85,2.53,4.1$ and 6.1 times $\mathrm{L} / \mathrm{D}$ ratios of 3,5 , 6,8 and 10 respectively when compared with unreinforced clay soil. This is a clear indication of improvement because of the reinforcement provided by stiffer fill material.

\section{REFERENCES}

[1] A.P. Ambily and S.R. Gandhi, "Experimental and Theoretical Evaluation of Stone Column in Soft Clay", Journal of Geotechnical and Geoenvironmental Engineering, April 2007.

[2] R.D. Barksdaleand, R.C. Bachus, "Design and Construction of Stone Columns”, FHWA report no. rd. 83/026, Vol. 1, Federal Highway Administration, Washington D.C., 1983.

[3] K.S. Beena, "Ground Improvement Using Stone Column”, Int. Conf. on Recent Advances in Geotechnical Earthquake Engineering and Soil Dynamics, 2010.

[4] BIS: 15284 (Part 1): 2003, "Design and Construction for Ground Improvement - Guidelines".

[5] K.R. Datye and S.S. Nagaraju, "Installation and Testing of Rammed
Stone Columns”, J. Geotech Div.,ASCE, Vol. 17, 1977.

[6] Hussein H. Karim, Mohammad M. MahmoodandRaida G. Renka, "Soft Clay Soil Improvement Using Stone Columns and Dynamic Compaction Techniques”, J. Geotech Div., ASCE.

[7] ImanHosseinpour, Mario Riccio and Marcio S.S. Almeida, "Numerical Evaluation of a Granualar Column Reinforced by Geosynthetics using Encasement and Laminated Disks" Journal of Geotextiles and Geomembranes, pp. 1-11, 2014.

[8] Karun Mani and K. Nigee, "A Study on Ground Improvement Technique using Stone Column”, J. Geotech Div., ASCE, 2014.

[9] Kausar Ali, "Effect of Encasement Length on Geosynthetic Reinforced Stone Columns", International Journal of Research in Engineering and Technology, Vol. 3, 2014.

[10] S.Murugan and K. Rajagopal, "Studies on the Behaviour of Single and Group of Geosynthetic Encased Stone Columns", J.Geotech.Geoenviron.Eng., Vol. 136, No.1, pp. 129-139, 2010.

[11] J. Pivarc, "Stone Columns - Determination of the Soil Improvement Factor”, Slovak Journal of Civil Engineering, Vol. XIX, No.3, pp. 1721, 2011.

[12] Pradip Das, “A Study of the BehaviorOf Stone Column in Local Soft and Loose Layered Soil”,Electronic Journal of Geotechnical Engineering, Vol.18, 2013.

[13] G.M. Smitha and C.S. Vishwanath, "Strengthening of Expansive Soil to Reduce Settlement”, International Journal of Research in Engineering and Technology, Vol.4,2014.

[14] Y.K. Tandel, C.H. Solanki and A.K. Desai "Reinforced Granular Column for Deepsoil Stabilization: A Review”, International Journal of Civil and Structural Engineering,Vol.2, No.3, 2017. 